\title{
Influence of chemical components La and heat treatment on the microstructure and mechanical property of $\mathrm{AlSi}_{7} \mathrm{Mg}$ aluminum alloy
}

\author{
Yongyue $\operatorname{Liu}^{1,2,3}$ \\ ${ }^{1}$ School of Materials Science and Technology, University of Science and \\ Technology Beijing, Beijing 100083, China \\ ${ }^{2}$ Forging Technology Center, Beijing Research Institute of Mechanical \\ and Electrical Technology, Beijing 100083, China \\ 3 Technology Center, Ningbo Heli Mould Technology Shareholding Co., \\ Ltd., Ningbo 315700, China
}

Received October 17, 2018

The effect of La additives on aluminum alloy $\mathrm{AlSi}_{7} \mathrm{Mg}$ and the casting temperature on its microstructure and mechanical properties was studied. It has been found that the addition of La has a significant improvement in the structure of the aluminum alloy and has a large effect on tensile strength and percentage elongation. When the La content was $0.2 \%$, the sample property was the best. With increasing solution temperature, the grain size of the samples increased, the spherical coefficient decreased, the density decreased, and the mechanical properties deteriorated. When the temperature of the solution was $540^{\circ}$ $\mathrm{C}$, the microstructure and mechanical properties of the samples were the best. This indicates that the proper addition of chemical components and the control of the temperature of the solution can improve the properties of the aluminum alloy billet.

Keywords: $\mathrm{AISi}_{7} \mathrm{Mg}$, aluminum alloy, chemical components, rare-earth metals, heat treatment, microstructure, mechanical properties.

Исследовано влияние добавок La в алюминиевый сплав $\mathrm{AlSi}_{7} \mathrm{Mg}$ и температуры литья на его микроструктуру и механические свойства. Обнаружено, что добавление La значительно улучшает структуру алюминиевого сплава и оказывает большое влияние на прочность к растяжению и процентное удлинение. При содержании La 0,2\% свойства образца наилучшие. С увеличением температуры раствора происходит увеличение размера зерен образцов и уменьшения сферического коэффициента. Соответственно уменьшается плотность и ухудшаются механические свойства. Когда температура раствора составляет $540^{\circ} \mathrm{C}$, микроструктура и механические свойства образцов имеют самые высокие показатели.

Вплив хімічних компонентів La i термообробки на мікроструктуру i механічні властивості алюмінісвого сплаву $\mathrm{AlSi}_{7} \mathrm{Mg}$. Yongyue Liu

Досліджено вплив добавок La в алюмінієвий сплав $\mathrm{AlSi}_{7} \mathrm{Mg}$ і температури лиття на його мікроструктуру і механічні властивості. Виявлено, що додавання La надає значне поліпшення структури алюмінієвого сплаву і має великий вплив на міцність до розтягнення i відсоткове подовження. Коли зміст La становить 0,2\%, властивості зразка найкращі. Зі збільшенням температури розчину розмір зерен зразків збільшувався, сферичний коефіцієнт зменшувався, щільність зменшилася, а механічні властивості погіршилися. Коли температура розчину досягає $540{ }^{\circ} \mathrm{C}$, мікроструктура і механічні властивості зразків мають найвищі показники. 


\section{Introduction}

Aluminum and aluminium alloy have light weight, low density, simple processing, high hardness and good corrosion resistance [1]. They have been widely used in fields such as mechanical manufacturing, transportation and aerospace [2]. Without destroying the original characteristics, improving the properties of aluminium alloys is the focus of current research [3]. Many researches have studied the influence factor of the performance of aluminium alloy. Fang et al. [4] added trace transitional element $\mathrm{Cr}$ to 7136 aluminum alloy and found that the addition of $\mathrm{Cr}$ made the distribution of alloy elements more uniform and improve the plasticity of aluminium alloy. Wang et al. [5] studied the effect of technological parameters on the microstructure and mechanical properties of ADC12 alloy. It was found that the spherical crystals generated dendrites and the tensile strength and elongation percentage decreased with the increase of solution temperature. With the increase of pressure, the crystal size became smaller, the spherical coefficient increased, and the mechanical properties improved. The optimal parameters were $605{ }^{\circ} \mathrm{C}$ solution temperature and $150 \mathrm{MPa}$ pressure. Gurusamy et al. [6] found that the melt and mold temperature had a significant effect on the properties of workpieces. The optimum melt and mold temperature of the composites were $85000{ }^{\circ} \mathrm{C}$ and $35000{ }^{\circ} \mathrm{C}$, respectively as the tensile strength and hardness of the materials were better under such temperature. Wang et al. [7] studied the effect of vanadium on 5083 aluminium alloy. It was found that the addition of vanadium inhibited the growth of grains in the process of recrystallization and improved the elongation percentage of aluminium alloy from $208 \%$ to $254 \%$. Therefore, in order to obtain better parts, it is necessary to optimize the design and casting process of aluminium alloy by various methods and find out the best casting conditions. In the present study, $\mathrm{AlSi}$ Mg aluminium alloy was taken as an example. The effects of chemical composition and heat treatment on the microstructure and mechanical properties of aluminium alloy were analyzed by adding different content of rare earth La in the manufacturing process and changing the solution temperature of aluminium alloy during casting.

\section{Aluminum and aluminum alloy}

Aluminum and its alloy have a very wide applications, second only to iron and steel. Related technologies of aluminum and aluminum alloy are developing rapidly. Various new types of aluminum alloys have been developed and put into use continuously, which suggests the high value of aluminum alloys [8-10].

Aluminum alloy materials have great application values in the industrial field [11]. The material and manufacturing process will have an impact on the physical and chemical properties of aluminum alloy [12]. Studying the composition and manufacturing process of different components can help analysis of the optimal performance of aluminum alloy under what conditions, so as to obtain better aluminum alloy workpiece. In view of chemical components and heat treatment, $\mathrm{AlSi}{ }_{7} \mathrm{Mg}$ aluminum alloy was taken as an example.

Different chemical components and content of the same chemical component will have different effects on the properties of aluminum alloy. In this study, rare earth La was added. The observation of the microstructure suggested that different content of La had different effects on the microstructure of the specimens.

\section{Experimental}

$\mathrm{AlSi}_{7} \mathrm{Mg}$ aluminum alloy was taken as an example in this study, and its composition is shown in Table 1.

A crucible was preheated to $500-550{ }^{\circ} \mathrm{C}$ and added with $\mathrm{AlSi}_{7} \mathrm{Mg}$ aluminum alloy for refining. After heating up to $800{ }^{\circ} \mathrm{C}, 0.4 \%$ and $0.6 \%$ Al-La intermediate alloy were added, respectively. The intermediate alloy was pressed into the solution and stirred evenly. When the temperature dropped to about $700-750{ }^{\circ} \mathrm{C}$, slag remover and refining agent were added and stirred. After $10 \mathrm{~min}$, it was processed by solution treatment with a mould which was preheated to $200{ }^{\circ} \mathrm{C}$. Then a specimen was obtained.

The casting process with different heat treatment was the same, but AL-La inter-

Table 1. The composition of $\mathrm{AISi}_{7} \mathrm{Mg}$ aluminum alloy

\begin{tabular}{|c|c|c|c|c|c|c|c||}
\hline $\mathrm{Al}$ & $\mathrm{Si}$ & $\mathrm{Mg}$ & $\mathrm{Cu}$ & $\mathrm{Fu}$ & $\mathrm{Mn}$ & $\mathrm{Ti}$ & $\mathrm{Zn}$ \\
\hline $91.78 \%$ & $7.5 \%$ & $0.28 \%$ & $0.2 \%$ & $0.16 \%$ & $0.04 \%$ & $0.03 \%$ & $0.01 \%$ \\
\hline
\end{tabular}


mediate alloy was not added. Different solution temperatures were selected in the stage of solution treatment. The temperature precision was controlled at $\pm 1{ }^{\circ} \mathrm{C}$ by PID temperature controller. The solution temperature was $550{ }^{\circ} \mathrm{C}, 545{ }^{\circ} \mathrm{C}$ and $540{ }^{\circ} \mathrm{C}$, respectively. Quenching was performed using 80 ${ }^{\circ} \mathrm{C}$ water after solution treatment, for 3 min, and then water was controlled for 2 min. After $12 \mathrm{~h}$, the specimen was put into a holding furnace and preserved at $150{ }^{\circ} \mathrm{C}$ for $3 \mathrm{~h}$. Then the test specimen was taken out and processed by air cooling until it was cooled to the room temperature.

The seven specimens obtained are shown in Table 2.

The microstructure of the specimens was observed by a LEICA $5000 \mathrm{M}$ metallographic microscope, and the spherical crystals were calculated by image-Pro Plus.

Grain size: $d=2 \sqrt{\frac{S}{\pi}}$

Spherical coefficient: $\alpha=\frac{4 \pi S}{C^{2}}$,

where $S$ stands for the cross-sectional area of spherical crystal and $C$ stands for circumference. The closer the spherical coefficient is to 1 , the rounder the crystal is.

Density: $\quad D_{n}=\frac{W_{a} \times D_{w}}{W_{a}-W_{w}}$, where $D_{n}$ refers to the density of the specimen, $D_{w}$ refers to water density, $W_{a}$ refers to the mass of the specimen in the air, and $W_{w}$ refers to the mass of the specimen in the water.

Void ratio: $P=\frac{D_{x}-D_{n}}{D_{x}} \times 100 \%$, where $D_{x}$ stands for the density of the specimen under $535{ }^{\circ} \mathrm{C}$.

Shrinking percentage: $\mu=\frac{L_{d}-L}{L_{d}}$, where $L_{\mathrm{d}}$ stands for the diameter of the impression and $L$ stands for the diameter of workpiece.

Tensile performance was tested using a tensile test machine. The tensile speed was $1 \mathrm{~mm} / \mathrm{min}$, and the elongation at break was measured using streak method.

Elongation at break: $\delta=\frac{C-C_{0}}{C_{0}} \times 100 \%$, where $C$ stands for the length of the specimen after fracture and $C_{0}$ stands for the length of the specimen before fracture.
Table 2. Parameters of different speci-

\begin{tabular}{|c|c|c|}
\hline $\begin{array}{c}\text { No. of test } \\
\text { specimen }\end{array}$ & $\begin{array}{c}\text { Content of La } \\
(\%)\end{array}$ & $\begin{array}{c}\text { Solution } \\
\text { temperature }\left({ }^{\circ} \mathrm{C}\right)\end{array}$ \\
\hline 1 & 0.1 & 540 \\
2 & 0.2 & 540 \\
3 & 0.3 & 540 \\
4 & 0.4 & 540 \\
5 & 0 & 550 \\
6 & 0 & 545 \\
7 & 0 & 540 \\
\hline
\end{tabular}

\section{Results and discussion}

The microstructure of the specimens 1 , 2,3 and 4 which had different content of La was observed under a microscope (Fig. 1).

It was found from Fig. 1 that different content of La had a significant effect on the microstructure of the specimens under the same casting conditions. When the content of La increased from $0.1 \%$ to $0.2 \%$, the microstructure of the test specimen was further refined, i.e., the grain was small, the distance between grains became narrowed and even, and the eutectic structure spherized. But when the content of La increased continuously, the refining effect on the structure disappeared, and the grains became rough and large. It indicated that the refining effect on the microstructure of the test specimen lost when the content of La exceeded $0.2 \%$.

It was found from Fig. 2 that the tensile strength was $164 \mathrm{MPa}$ when the content of La was $0.1 \%$ and significantly increased to $207 \mathrm{MPa}$ when the content of La increased to $0.2 \%$. But with the continuous increase of content of La, the tensile strength of the test specimen declined. The tensile strength of the test specimen was $169 \mathrm{MPa}$ when the content of La was $0.3 \%$ and $168 \mathrm{MPa}$ when the content of La was $0.4 \%$. It indicated that the structure property of the test specimen deteriorated when the content of La exceeded $0.2 \%$.

In conclusion, the morphology and mechanical properties of the test specimen were the best when the content of La was $0.2 \%$.

The microstructure of specimen $\mathrm{X}, \mathrm{Y}$ and $\mathrm{Z}$ whose conditions were the same except solution temperature observed under a microscope is shown in Fig. 3.

Fig. 3 shows that different heat treatment techniques affected the microstructure of the specimen. The microstructure of the 

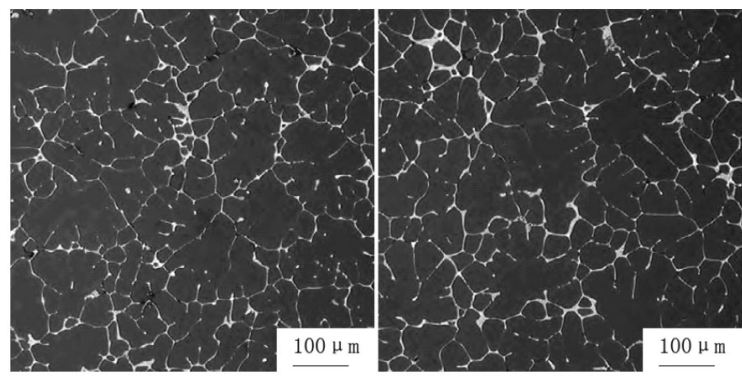

1、 $0.1 \% \mathrm{La}$

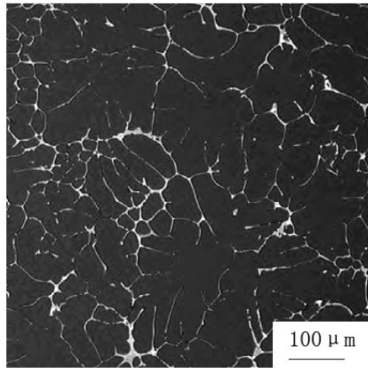

3、 $0.3 \% \mathrm{La}$
2、 $0.2 \% \mathrm{La}$

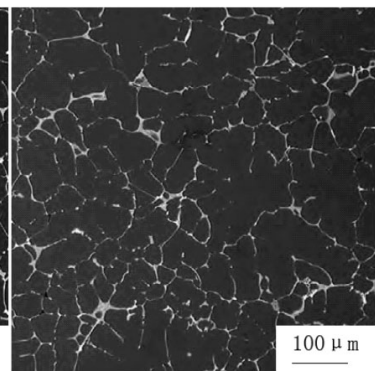

4、0. 4\%La

Fig. 1. The microstructure of the specimens which had different content of La

specimen was not completely separated, the grains were coarse, and the grains were adhered at $550{ }^{\circ} \mathrm{C}$; short dendrites appeared, but not all of them were separated at $545^{\circ} \mathrm{C}$; the spherical structure began to appear and there was small intervals between the grains at $540{ }^{\circ} \mathrm{C}$.

The changes of the average grain size and spherical coefficient are shown in Fig.4.

Fig. 4 exhibits that the average grain size increased with the increase of temperature. The average grain size was about 70 $\mu \mathrm{m}$ and the grain size was relatively coarse when the temperature was $550{ }^{\circ} \mathrm{C}$. When the temperature was $540{ }^{\circ} \mathrm{C}$, the grain size was reduced to about $35 \mu \mathrm{m}$. The average spherical coefficient decreased with the increase of temperature. The average spherical coefficient was about 0.3 at $550{ }^{\circ} \mathrm{C}$ and 0.75 at $540{ }^{\circ} \mathrm{C}$. The results showed that the grain size of the specimen decreased slowlv

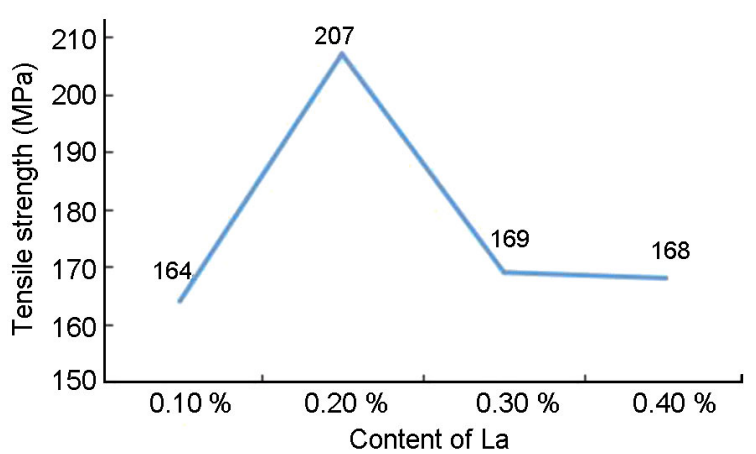

Fig. 2. The changes of tensile strength

and the shape became more rounded with the decrease of solution temperature.

Fig. 5 exhibits that different heat treatment affected the density and void rate of the specimen. The density of the specimen was only about $2.5 \mathrm{~g} / \mathrm{cm}^{3}$ at $550{ }^{\circ} \mathrm{C}$ and 2.9 $\mathrm{g} / \mathrm{cm}^{3}$ at $540{ }^{\circ} \mathrm{C}$. It indicated that the density of the specimen was high under low solution temperature. The void rate of the specimen increased with the increase of temperature. When the temperature was $540{ }^{\circ} \mathrm{C}$, the void rate of the specimen was the smallest, close to $0 \%$.

The changes of other indicators are shown in Table 3.

It could be found from Table 3 that the tensile strength and elongation percentage of the specimen decreased with the increase of solution temperature. At $540{ }^{\circ} \mathrm{C}$, the tensile strength of the specimens is the highest, $228 \mathrm{MPa}$, and the elongation percentage was also the highest, $12.6 \%$. The shrinking percentage of the specimen increased with the increase of solution temperature. At lower temperature, the shrinking percentage of the specimen was small, and at $540{ }^{\circ} \mathrm{C}$, the shrinkage was only $2.3 \%$.

Different chemical components and content of the same chemical component will have different effects on the properties of aluminum alloy. In this study, rare earth La was added. The observation of the microstructure suggested that different content

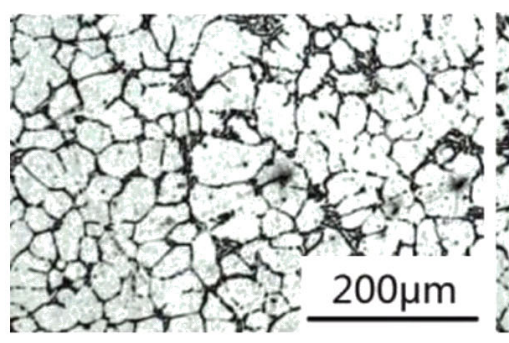

5、 $550^{\circ} \mathrm{C}$

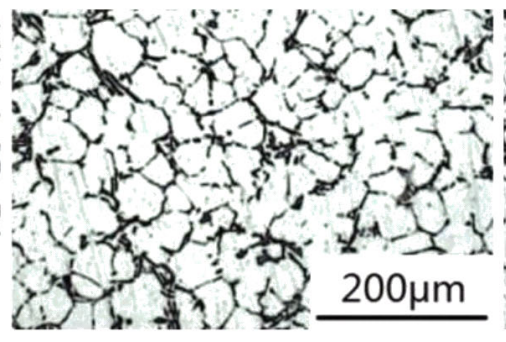

6、 $545^{\circ} \mathrm{C}$

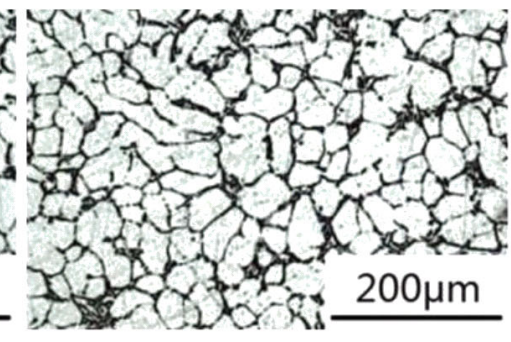

7、 $540^{\circ} \mathrm{C}$

Fig. 3. The microstructure of the specimens under different pouring temperatures. 


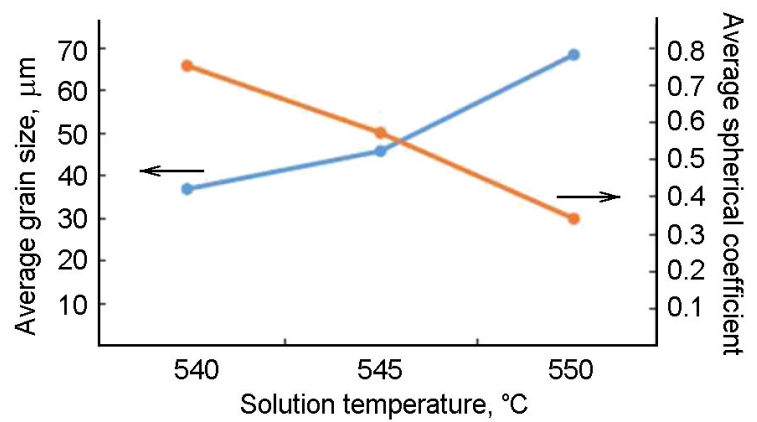

Fig. 4. The average grain size and spherical coefficient of the specimen under different solution temperatures.

of La had different effects on the microstructure of the specimens. The addition of La could obviously refine the grain size and reduce the distance between dendrites. It was found that La had a significant refining effect on the microstructure of the test specimen when the content of La was $0.2 \%$. However, it was also found that the microstructure of the specimens was not improved with the increase of content of La after $0.4 \%$, indicating that the effect was maximum when the content of La was $0.2 \%$. The same conclusion could be drawn from the analysis of mechanical properties: the density significantly improved, the void rate decreased, the tensile strength and elongation percentage increased, and the shrinkage rate of the specimen decreased when the content of La was $0.2 \%$, but the addition of La also produced negative effects on the mechanical properties of the specimens. It indicated that $0.2 \%$ La in $\mathrm{AlSi}_{7} \mathrm{Mg}$ aluminum alloy had a significant effect on the overall performance of aluminum alloy.

Different heat treatment have different effects on specimens [13]. In this study, the solution temperature in the process of heat treatment was analyzed. It was found that the microstructure and mechanical properties of the specimen changed under different solution temperatures. When the temperature was low, the microstructure of the specimen obtained was better. With the decrease of solution temperature, the microstructure of the test specimen became rounder and gradually produced globular structure, and the microstructure of the test specimen was the best when the solution temperature was $540{ }^{\circ} \mathrm{C}$. The analysis of the mechanical properties suggested that the density, void rate and tensile strength of workpiece were better under low solution

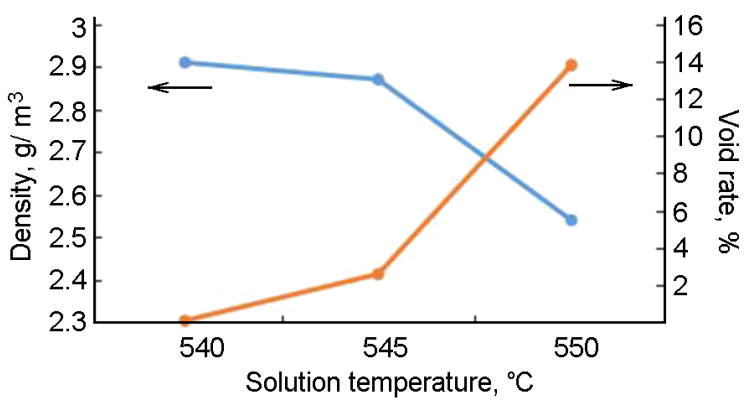

Fig. 5. The density and void rate of the specimen under different solution temperatures.

Table 3. The relationship of solution temperature with tensile strength, elongation percentage and shrinking percentage

\begin{tabular}{||c|c|c|c||}
\hline Solution temperature $/{ }^{\circ} \mathrm{C}$ & 540 & 545 & 550 \\
\hline Tensile strength $(\mathrm{MPa})$ & 228 & 225 & 212 \\
\hline Elongation percentage (\%) & 12.6 & 12.3 & 10.1 \\
\hline Shrinking percentage (\%) & 2.3 & 2.5 & 3.8 \\
\hline
\end{tabular}

temperature, while high solution temperature would reduce the quality of workpiece. At high temperature, the molten metal would oxidize and generate oxide inclusions, which might lead to the decrease of metal density, appearance of cracks and burrs and decline of mechanical property.

\section{Conclusion}

This study focused on the influence of chemical components and heat treatment on $\mathrm{AlSi}_{7} \mathrm{Mg}$ aluminium alloy workpiece. The microstructure and mechanical property of the specimen under different content of La and solution temperatures was analyzed. It was found that $0.2 \%$ La could significantly refine grain size and improve morphology, and specimens produced under low solution temperature had higher spherical degree, better morphology, larger density, low void rate and better mechanical property. The quality of workpiece was the best when the content of La added was $0.2 \%$ and the solution temperature was $540{ }^{\circ} \mathrm{C}$.

\section{References}

1. R. Horvath, A. Dregelyi-Kiss, Measurement, 65, 181 (2015).

2. R. Menini, Z. Ghalmi, M. Farzaneh, Cold Reg. Sci. Technol., 65, 65 (2011).

3. S. J. Yan, S. L. Dai, X. Y. Zhang et al., Mater. Sci. Eng. A, 612, 440 (2014).

4. H. Fang, H. Liu, H. Yin et al., Hot Work. Technol., 0(8), 74 (2017). 
5. S. Z. Wang, M. Zhao, M. L. Hu et al. Chin. J. Nonferr. Metals, 25, 1428- (2015).

6. P. Gurusamy, S. B. Prabu, R. Paskaramoorthy, Adv. Manufact. Proc., 30, 367 (2015).

7. X. J. Wang, F. G. Cong, Q. F. Zhu, J. Z. Cui, Sci. China Technol. Sci., 55, 5104 (2012).

8. B. Han, W. Tao, Y. Chen, H. Li, Opt. Laser Technol., 93, 99 (2017).
9. H. J. Liu, X. Zhang, L. F. Xiao, J. Mach. Design, 28, 18 (2011).

10. H. Dan, Z. Zhu, H. Geng et al., J. Mater. Eng., 45, 662 (2017).

11. M. T. Azhagan, B. Mohan, A. Rajadurai, Int. J. Eng. Technol., 6, 183 (2014).

12. Y. Guo, M. Li, H. Xu, et al., Int. J. $A d v$. Manufact. Technol., 97, 1995 (2018).

13. B. Poulin, R. Mcneil, Mater. Sci. Forum, 830831, 131 (2015). 